J. Product. \& Dev., 22(3): 635-656 (2017)

\title{
IMPACT OF SUBSTITUTING SOYA BEAN MEAL BY MORINGA (Moringa oleifera) LEAVES MEAL IN THE DIET ON GROWTH PERFORMANCE, NUTRIENTS DIGESTIBILITY, BLOOD CONSTITUENTS AND CARCASS TRAITS OF GROWING RABBITS.
}

R.M. Abo El-Haded; Abd El-Rahim, M.I. and El-Kerdawy, D.A.

Department of Animal and Poultry Production, Faculty of Technology \& Development, Zagazig University, Zagazig, Egypt.

\section{ABSTRACT}

In completely randomized block design, seventy two weaner New Zealand White (NZW) rabbits, 4-5 weeks old and with an average body weight of $458 \pm 7 g$ were used in a feeding trial for 56 days. The present study aimed to ascertain the effect of feeding diets containing different levels of Moringa oleifera leaves meal (MOLM) asa substitution forsoya bean meal on growth performance, nutrients digestibility, haematological and biochemical blood parameters and carcass traits of rabbits. Therabbits were randomly divided into three experimental groups of 24 rabbits per each and they distributed on three different pelleted diets containing 0, 12.5 and $19 \%$ MOLM to substitute 0, 50 and $75 \%$ of soya bean meal in the basal diet,respectively.

The results of the study revealed that chemical composition (\%) ofcomposite sample of MOLM resulted from 6 successive cuts of moringa plants recorded: $90.03 \mathrm{DM}, 27.44 \mathrm{CP}, 8.13 \mathrm{EE}, 8.77 \mathrm{CF}$, 34.63 NFE and $11.06 \%$ Ash, indicating high crude protein, fats and minerals contents in MOLM.

The final body weight $(F W)$, daily weight gain $(D W G)$ and relative growth rate $(R G R)$ were insignificantly increasedwith rabbits fed MOLM diets. Feed intake was significantly $(P<0.01)$ declined with rabbits fed $19 \%$ MOLM diet than those fed control or $12.5 \%$ MOLM diet. However, Feed conversion ratio (FCR), growth performance index (GPI) and economic efficiency were significantly $(P<0.01)$ improved with rabbits fed MOLM diets compared with those fed the control diet.

Crude protein $(C P)$ and $O M$ digestibility coefficients and nutritive value (\%) of MOLM diets expressed as DCP and TDN were significantly higher $(P<0.01)$ with rabbits fed MOLM diets than with 
those fed the control diet, while EE, CF and NFE digestibility coefficients were not affected by the dietary treatments.

The haematological and biochemical blood parameters were not significantly affected by the dietary treatments, with exception of $R B C s$, total proteinand globulin which were significantly $(P<0.01)$ higher, whereas $M C H$ and cholesterol levels were significantly $(P<$ $0.05)$ lower with rabbits fed MOLM diets. However, all the haematological and biochemical parameters values of rabbit groups were within the normal physiological range.

Carcass traits were not significantly influenced by the dietary treatments. Internal organs of rabbits in all groups, including liver, kidney, heart, lungs and spleen appeared normal in size and did not show any signs of toxicity.

Conclusively, the results of the present study suggest that MOLM possess good protein quality for growth of rabbits and can be incorporated in the growing rabbits diets up to $19 \%$ in replacement up to $75 \%$ of soya bean meal without any detrimental effects on growth performance, nutrients utilization, blood constituents and carcass traits.

Key words: Rabbits, MOLM, soya bean meal, growth performance, nutrients digestibility, blood parameters, carcass traits.

\section{INTODUCTION}

Rabbits can plays a major role in solving the protein gap in developing countries, where average consumption is still far below the recommended standard level (FAO, 2014). Many people like rabbits meat consumption due to its high nutritional value and the low cholesterol content (De Blas and Wiseman, 2010).

Despite these advantages, rabbit production nowadays has been decreased in Egypt due to many problems; the highcost of feeding is considered the most important. This has been attributed to the feedstuffs shortage, especially the conventional protein and energy sources like soya bean meal and maize grains which mostly are imported from the abroad with foreign currency.

Recently, the interest has been increased towards the utilization of moringa (Moringa oleifera) leaves meal as a good protein source in the diets of farm animals as asubstitutefor the traditional protein sources such as soya bean, sunflower and ground nut meals (Sarwatt et al, 2002; Asaolu et al, 2009; 
Fadiyimu et al, 2010; Mendieta-Araica et al, 2011; El Tazi, 2014; Melesse et $a l, 2011$ and Ghomsi et al, 2017) in order to decrease the feeding costs.

Sarwatt et al., (2004) reported that moringa foliage is a potential inexpensive protein source for livestock feeding. The advantages of using moringa as a protein source are numerous and include the fact that it is a perennial plant that can be harvested several times in one growing season. One hectare cultivated area gives about 240 tons or more green forage resulted from 8 cuts in the year (Foidl et al, 2001).

The literature showed that moringa leaves are considered good source of high quality protein in the feed of farm animals, it rich in both essential and sulfur-containing amino acids and true protein represents about $87 \%$ of the total crudeprotein in the leaves(Makkar and Becker, 1997, Fuglie, 2001, Bennett et al., 2003, Siddhuraju and Becker, 2003; Yang et al, 2006, Ferreira et al., 2008; Nuhu, 2010 and Moyo et al., 2011). Moringa leaves contain high levels of minerals (about 10\%), particularly $\mathrm{Ca}$ and Fe. They are also rich in a wide range of vitamins such as $B$-carotene, ascorbic acid, vitamin B1, B6 and niacin (Price, 2007; Sanchez, 2006) , as well as flavonoids (quercetin and kaempferol), which are known to be more potent antioxidants than ascorbic acid (Yang et al, 2006). Moringa leaves may thus be used as an antioxidant feed (Makkar et al., 2007). They have a relatively high concentration of lipids (5 up to 10\%) with an important proportion (33 to 45\%) of $\alpha$-linolenic acid (Moyo et al., 2011; Olaofe et al., 2013).

Information regarding the effect of feeding moringa leaves meal on productive performance of rabbits under the Egyptian conditions is lacking. The present study was carried out to investigate the effect of substitution of 50 and $75 \%$ of soya bean mealin the diet for moringa oleifera leaves meal (MOLM) on growth performance, blood constituents, nutrients digestibility andcarcass traits of growing rabbits.

\section{MATERIALS AND METHODS}

The experimental work of the present study was carried out at Rabbits Research Unit, Department of Animal and Poultry Production, Faculty of Technology and Development, Zagazig University, Zagazig, Egypt. The experimental work was initiated in December 2015 and terminated in February, 2016. The laboratory work was performed at Central Lab for Soil, Foods and Feedstuffs (International Accredited Laboratory and has ISO 17025, since 2012), Faculty of Technology \& Development, Zagazig University, Zagazig, Egypt. 


\section{Cultivation of moringa plant and preparation of moringa leaves for the study:}

Moringa plant was cultivated in the experimental Station of Faculty of Technology \& Development; Zagazig University. The farm is located in Ghazala Village (20 km far from Zagazig City, Egypt) of clay soil and the ambient temperature during 8 months of plantation was between 22$35^{\circ} \mathrm{C}$. The seeds of moringa were cultivated in March, 2015 at rate of $20 \mathrm{~kg}$ /feddan (One feddan equal $4200 \mathrm{~m}^{2}$ area) at the spaces of $30 \times 60 \mathrm{~cm}$ for intensive cultivation. Irrigation of moringa plants was each 15 days. Rabbits faecesresulted from the rabbit research unit of Faculty of Technology \& Developmentwas used as organic fertilizer to moringa plants. The $1^{\text {st }}$ cut for green forage was taken after 90 days of planting and the following cuts ( 6 cuts) were taken each 45 days after there. Moringa harvesting (cuts) was at $1.25 \mathrm{~m}$ height. The leaves were harvested and the stems were removed. The leaves of each cut were air-dried under shade until the moisture of collected leaves reached $10-12 \%$. The dry leaves were stored in polyethylene bags at room temperature $\left(25^{\circ} \mathrm{C}\right)$ until formulation of the experimental diets in the Feed Mill. Composite sample from each cut of fresh and air dry moringa leaves was taken for the chemical analysis.

\section{The experimental animals and their management:}

In completely randomized block design, seventy two (72) weaner rabbits of mixed sexes and aged between 4-5 weeks old and with an average body weight of $458 \pm 7 \mathrm{~g}$ were used in a feeding trial for 56 days.

The rabbits were purchased from special commercial farm located in Meet Ghamr, Dakahliya Governorate, Egypt. They animals were randomly divided into three experimental groups of 24 rabbits per each with 3 rabbits in 8 replicates.The animals were housed ( 3 rabbits together) in flat deck wire cages $(50 \times 55 \times 40 \mathrm{~cm})$, provided with galvanized feeders and automatic drinkers nipple. The rabbit groups were fed three experimental pelleted diets, containing MOLM at levels of zero (control), 12.5 and 19\% to substitute zero, 50 and $75 \%$ of soya bean meal, respectively in the basal diet (control). Chemical analysis of moringa oleifera leaves meal and soya bean meal was done before formulation the experimental diets (Table 1). Formulation and chemical composition of the experimental diets are shown in Table 2. The experimental pelleted diets were manufactured in Atmeda Feedstuffs Mill, Meet Ghamr, Dakahliya Governorate, Egypt. The experimental diets were formulated to be iso nitrogenous and iso caloric and meet the nutrient requirements of growing rabbits according to NRC (1977). The diets were offered to rabbits adlibitum and tap water was available to rabbits all the time. The rabbits 
Table 1. Chemical analysis (\%) of ingredients used in formulation of the experimental diets:

\begin{tabular}{|l|l|l|l|l|l|l|}
\hline Ingredients & DM & CP & EE & CF & NFE & Ash \\
\hline MOLM $^{*}$ & 90.03 & 27.44 & 8.13 & 8.77 & 34.63 & 11.06 \\
\hline Soya bean meal & 90.15 & 42.79 & 2.08 & 7.27 & 32.38 & 5.63 \\
\hline Yellow corn & 90.59 & 8.81 & 4.18 & 3.82 & 71.47 & 2.31 \\
\hline Barley grains & 92.14 & 11.43 & 2.18 & 6.56 & 69.28 & 2.69 \\
\hline Wheat bran & 89.29 & 14.11 & 3.12 & 11.51 & 56.34 & 4.21 \\
\hline Alfalfa hay & 87.56 & 14.25 & 2.35 & 26.48 & 35.13 & 9.35 \\
\hline
\end{tabular}

* Composite sample of Moringa oleifera leaves meal (MOLM) was taken from 6 successive cuts of moringa plants.

were maintained in ventilated room under the same managerial and hygienic conditions. The experiment lasted for eight weeks.

\section{Data collection for calculating the growth performance traits:}

At the start of the experiment, all the rabbits were weighed before allotting them to their feeding treatments. The rabbits were weighed weekly to determine the weight gain. The experimental diets were offered ad libitum in the morning at about $09.00 \mathrm{hr}$. The quantity of feed offered daily and leftover were weighed to determine the daily feed intake, while feed conversion ratio (FCR) was determined by dividing the total feed intake by the total weight gain. Mortality and growth rates were calculated. Relative growth rate of rabbits was calculated according to Broody (1945) by using the following equation:

Relative growth rate $(\mathrm{RGR})=[(\mathrm{W} 2-\mathrm{W} 1) \times 100] /[1 / 2(\mathrm{~W} 2+\mathrm{W} 1)]$.

Where, $\mathrm{W} 1=$ The initial body weight $(\mathrm{g})$, and $\mathrm{W} 2$ = The final body weight $(\mathrm{g})$.

Growth performance index (GPI) was calculated according to North (1981) as follow:

GPI $=($ Final live body weight, $\mathrm{Kg} /$ Feed conversion ratio $) \times 100$.

\section{Economic efficiency of the experimental diets:}

Economicfeed efficiency (EE) was calculated according to the prevailing prices of the experimental diets and rabbit's meat, during year of 2016. It was calculated as follows:

$\mathrm{EE}=$ Net revenue $/$ Total feed cost

While, Net revenue $=$ Selling price of total weight gain - Total feed cost . 
Table (2) Ingredients and chemical composition (\%) of the experimental diets.

\begin{tabular}{|l|c|c|c|}
\hline \multirow{2}{*}{ Items } & \multicolumn{3}{|c|}{ The experimental diets } \\
\cline { 2 - 4 } & $\begin{array}{c}\text { Control } \\
\text { (0.0 \% MOLM) }\end{array}$ & $\begin{array}{c}\mathbf{1 2 . 5 \%} \\
\text { MOLM }\end{array}$ & $\begin{array}{c}\mathbf{1 9 \%} \\
\text { MOLM }\end{array}$ \\
\hline Ingredients (\%): & 17 & 17 & 17 \\
Yellow corn & 18 & 18 & 18 \\
Barley grains & 26 & 26 & 26 \\
Wheat bran & 16 & 8 & 4 \\
Soya bean meal & - & 12.5 & 19 \\
Moringa leaves meal & 20 & 15.5 & 13 \\
Alfalfa hay & 2 & 2 & 2 \\
Lime stone & 0.5 & 0.5 & 0.5 \\
Table salt & 0.3 & 0.3 & 0.3 \\
Premix for growth* & 0.1 & 0.1 & 0.1 \\
Dl - methionine & 0.1 & 0.1 & 0.1 \\
Anti - Fungal powder & $\underline{\mathbf{1 0 0}}$ & $\mathbf{1 0 0}$ & $\mathbf{1 0 0}$ \\
\hline Total & & & \\
Chemical composition (\%): & 90.10 & 90.70 & 91.22 \\
Dry matter (DM) & 2650 & 2703 & 2697 \\
ME (kcal/kg) ** & 16.83 & 16.59 & 16.40 \\
Crude protein (CP) & 11.22 & 10.60 & 10.42 \\
Crude fibre (CF) & 2.71 & 3.46 & 3.74 \\
Ether extract (EE) & 49.50 & 49.64 & 49.92 \\
Nitrogen free extract (NFE) & 9.84 & 10.41 & 10.74 \\
Ash & 0.88 & 1.10 & 1.16 \\
Total calcium (Ca) & 0.52 & 0.52 & 0.55 \\
Total phosphorous (P) & 0.92 & 1.35 & 1.57 \\
Lysine*** & 0.99 & 0.91 & 0.61 \\
Methionine +cysteine*** & 0.99 \\
\hline
\end{tabular}

*Each 3 kilograms of premix contains: Vit. A 12000000 IU, Vit. $\mathrm{D}_{3} 1500000 \mathrm{IU}$, Vit. E 50 gm, Vit. $K_{3} 2$ gm,Vit. $B_{1} 2$ gm, Vit. $B_{2} 6$ gm, Vit. $B_{12} 0.01$ gm, Chol.Chlod 1200 gm, Biotine $0.2 \mathrm{gm}$, Niacine $50 \mathrm{gm}$, Pantothenic acid $20 \mathrm{gm}$, Folic acid $5 \mathrm{gm}$, Magnesium $400 \mathrm{gm}$, Copper $5 \mathrm{gm}$, Iodin $0.75 \mathrm{gm}$, Selenium $0.1 \mathrm{gm}$, Iron $75 \mathrm{gm}$, Manganese $30 \mathrm{gm}$, Zinc $70 \mathrm{gm}$.

**It was determined according to Kalogen (1985)

*** It was calculated according to NRC (1977).

\section{Digestibility trial:}

At the end of feeding trial period (56 days), five rabbits were randomly taken from each group to conduct a digestibility experiment. The animals were housed individually in metabolic cages $(40 \times 50 \times 50 \mathrm{~cm})$ which allow collecting the faeces and urine separately. Each cage was equipped 
with an automatic drinker nipple and a manual feeder. The experimental period lasted 8 days, three days as a preliminary period for adaptation and five days as a main period for accounting the daily feed consumption and faeces output (Perez et al., 1995).

The collection was performed at approximately 09:00 h. each morning before offering the daily ration, and then $10 \%$ of the total faeces output were dried at $65^{\circ} \mathrm{C}$ for $24 \mathrm{~h}$ and stored in polyethylene bags till the end of the experiment .All the collected faeces for each animal were mixed, then representative faeces samples were ground for chemical analysis. The apparent nutrients digestibility coefficients were determined using the total collection method described by Perez et al. (1995) according to the following classical formula:

Apparent nutrient digestibility $(\%)=100 \times \mathrm{NI}-\mathrm{NE} / \mathrm{NI}$

Where: $\mathrm{NI}=$ Nutrient intake, $\mathrm{NE}=$ Nutrient excreted in faeces.

Nutritive value of the experimental diets expressed as TDN (Total Digestible Nutrients) was calculated according to the equation suggested by Cheeke et al. (1982) as follows:

$$
\mathrm{TDN} \%=\mathrm{DCP} \%+\mathrm{DCF} \%+\mathrm{DNFE} \%+\mathrm{DEE} \% \times 2.25 \text {. }
$$

Where: $\mathrm{DCP}=$ Digestible Crude Protein, $\mathrm{DCF}=$ Digestible Crude Fiber, DNFE $=$ Digestible Nitrogen Free Extract and DEE =Digestible Ether Extract.

$\mathrm{ME}(\mathrm{Kcal} / \mathrm{Kg}$ diet $\mathrm{DM}$ ) of the experimental ration was calculated according to the following formula of Kalogen (1985):

$\mathrm{ME}(\mathrm{Kcal} / \mathrm{Kg} \operatorname{diet} \mathrm{DM})=(0.588+0.164 \mathrm{X}) 239$

Where $\mathrm{X}=$ Dry matter $(\mathrm{DM})$ digestion coefficient of the experimental diet.

\section{Blood samples collection:}

At end of the $8^{\text {th }}$ week of trial, 5 rabbits from each group were randomly chosen and fasted for 24 hrs. The rabbits were weighed and handly slaughtered and blood sample was taken from each rabbit into two clean and dry heparinized and non-heparinized tubes. Blood samples in the heparinized tubes were analyzed for the haematological parameters $(\mathrm{RBCs}=$ Red blood cells, $\mathrm{WBCs}=$ White blood cells, HCT $=$ Haematocrit, $\mathrm{MCV}$ =Mean corpuscular volume, $\mathrm{MCH}=$ Mean corpuscular haemoglobin, $\mathrm{MCHC}=$ Mean corpuscular haemoglobin concentration, Neutrophils and Lymphocytes)..

Blood samples in the non-heparinized tubes were centrifuged at 3000 r.p.m for 15 minutes and then blood serum was taken to determine the levels and activity of some biochemical parameters that indicate the health status of animals (total protein, albumin, globulin, total bilirubin, urea-N, creatinine, total cholesterol, ALT and AST). Blood haematological and 
biochemical analysis was performed in one of the accredited medicinal analytical labs.

\section{Blood haematological and biochemical analyses:}

Packed cell volume (PCV) was determined by spinning about $75 \mu 1$ of each blood sample in heparinized capillary tube in a haematocrit centrifuge for about 5 minutes and read on haematocrit reader as described by Walkeret al. (1990), while erythrocytes (RBC) and leucocytes (WBC) counts and differential white blood counts (neutrophils, eosinophils, basophils, lymphocytes and monocytes) were determined using haemocytometer method as described by Walker et al. (1990). The haemoglobin $(\mathrm{Hb})$ concentration and the blood constants: mean cell haemoglobin $(\mathrm{MCH})$, mean corpuscular volume $(\mathrm{MCV})$ and mean corpuscular haemoglobin concentration $(\mathrm{MCHC})$ were determined using cyanet haemoglobin method and appropriate formula respectively as described by Jain (1986).

\section{Carcass traits:}

After taking the blood samples and complete bleeding, slaughtered animals were de-skinned, dressed out and the hot carcass including head was weighed and recorded. Edible offals; liver, heart, spleen and kidneys, were weighed.

Dressing $\%=($ Carcass weight + Giblet weight $/$ pre-slaughter weight $) \times 100$.

\section{Chemical analysis.}

The chemical analysis of the feed ingredients and experimental diets used in the study were determined in Central laboratory for Soil, Foods and Feedstuffs (International Accredited Lab and has ISO 17025 since 2012), Faculty of Technology \& Development, Zagazig University, Zagazig, Egypt. Chemical analysis of feed ingredients and the experimental diets was performed according to the International Standard Methods (ISO). Moisture content was doneaccording to ISO 6496: 1999, crude ash according to ISO 5984:2002, crude protein, according to ISO 5983-1:2002, crude fat, according to the method described in Official Journal of the European Union (EN), 2009, L54/37, Volume 52, and crude fiber was according to the method described in Official Journal of the European Union (EN), 2009, L54/ 40, Volume 52. Mineral elements contents were determined by atomic absorption spectrophotometry using ISO 6869:2000. Phosphorus was determined according to ISO 6491:1998. 


\section{Statistical analysis}

Data obtained in this study were subjected to the analysis of variance as a completely randomized block design according to Snedecor and Cochran (1982) and using the Linear Model Program of SPSS (2004). The differences between the treatments means were separated by Duncan Multiple Range Test (Duncan, 1955). Data in percentage values were transformed with the arcsine square root procedure to normalize variance before analysis. Statistical Model was as follow:

$$
\mathrm{Yij}=\mu+\mathrm{Ti}+\mathrm{e}_{\mathrm{ij}}
$$

Where: $\mathrm{Yij}=$ The independent variable $\mu=$ The overall mean, $\mathrm{Ti}=$ The effect of treatment and eij $=$ The experimental error.

\section{RESULTS AND DISCUSSION}

\section{Growth performance traits:}

The results of growth performance traits of rabbits fed diets containing different levels of MOLM as substitution for soya bean meal are presented in Table 3.

The mean values obtained for final body weight (FW), daily weight gain (DWG)and relative growth rate (RGR) were insignificantly increasedwith rabbits fed MOLM diets. Feed intake was significantly influenced $(\mathrm{P}<0.01)$ by the dietary treatments and recordedthe lowestvalue $(\mathrm{P}<0.01)$ with rabbits fed $19 \%$ MOLM diet. However, feed conversion ratio (FCR) andgrowth performance index (GPI)were significantly $(\mathrm{P}<0.01)$ improved with rabbits fed MOLM diets compared with those fed the control diet (without MOLM).Feed conversion ratiorecorded 3.32, 2.98and 2.78, whereas, GPI (\%) recorded 48.03, 57.02 and $59.27 \%$ for rabbits fed zero (control), 12.5 and $19 \%$ MOLM diets,respectively.The economic efficiency was significantly higher with rabbits fed MOLM diets than with those fed the control diet and positively correlated to the level of MOLM in the diet. Mortality rate showedinsignificantly decrease with rabbits fed MOLM diets compared with those fed the control diet.

The lower feed intake of rabbits fed 19\% MOLM diet may bedue to the presence of saponins and phenol compounds in moringa leaves .These compounds have bitter and pungent taste and make the diet less palatable when its quantity increased with increasing the level of MOLMin the $\operatorname{diet}($ Ufeleet al, 2013).

The improvement in FCR and GPI with rabbits fed MOLM diets in spite of decreasing the daily feed intake could be attributed to the presence 
Table 3. Growth performance traits $(\mathrm{X} \pm \mathrm{SE})$ of growing NZW rabbits fed for 8 weeks the experimental diets from 5 to 13 weeks of age.

\begin{tabular}{|c|c|c|c|c|}
\hline \multirow[t]{2}{*}{ Parameters } & \multicolumn{3}{|c|}{ Experimental groups (\%) } & \multirow[t]{2}{*}{ Sig. } \\
\hline & $\begin{array}{c}\text { Control } \\
(0.0 \text { MOLM })\end{array}$ & $\begin{array}{c}12.5 \\
\text { MOLM }\end{array}$ & $\begin{array}{c}19.0 \\
\text { MOLM }\end{array}$ & \\
\hline Initial body weight(g) & $457.75 \pm 7.01$ & $458.00 \pm 7.38$ & $457.71 \pm 6.32$ & NS \\
\hline Final body weight(g) & $1568.29 \pm 47.20$ & $1677.32 \pm 70.17$ & $1630.50 \pm 42.32$ & NS \\
\hline \multicolumn{5}{|l|}{ Body weight gain(g) } \\
\hline 5-9WK & $408.25 \pm 24.43$ & $469.17 \pm 28.16$ & $438.71 \pm 14.87$ & NS \\
\hline $9-13 \mathrm{WK}$ & $711.67 \pm 33.81$ & $737.50 \pm 54.42$ & $736.23 \pm 35.24$ & NS \\
\hline $5-13 \mathrm{WK}$ & $1109.52 \pm 45.98$ & $1215.23 \pm 66.87$ & $1172.14 \pm 41.44$ & NS \\
\hline \multicolumn{5}{|l|}{ Daily body weight gain(g) } \\
\hline 5-9WK & $14.58 \pm 0.87$ & $16.76 \pm 1.01$ & $15.67 \pm 0.53$ & NS \\
\hline 9-13WK & $25.42 \pm 1.21$ & $26.34 \pm 1.95$ & $26.29 \pm 1.26$ & NS \\
\hline $5-13 \mathrm{WK}$ & $19.81 \pm 0.82$ & $21.70 \pm 1.19$ & $20.93 \pm 0.74$ & NS \\
\hline \multicolumn{5}{|l|}{ Relative growth rate (\%) } \\
\hline $5-9 \mathrm{WK}$ & $60.48 \pm 2.62$ & $66.47 \pm 2.54$ & $64.55 \pm 1.66$ & NS \\
\hline 9-13WK & $58.98+2.59$ & $55.52 \pm 3.21$ & $57.88+2.05$ & NS \\
\hline $5-13 \mathrm{WK}$ & $108.67 \pm 2.14$ & $111.80 \pm 2.81$ & $111.61 \pm 1.82$ & NS \\
\hline \multicolumn{5}{|l|}{ Daily Feed intake (g) } \\
\hline 5-9WK & $47.88 \pm 1.44^{\mathrm{a}}$ & $49.40 \pm 0.74^{\mathrm{a}}$ & $44.29 \pm 1.32^{b}$ & $*$ \\
\hline $9-13 \mathrm{WK}$ & $83.48+1.36^{\mathrm{a}}$ & $80.21 \pm 1.38^{\mathrm{a}}$ & $71.58 \pm 0.39^{\mathrm{b}}$ & $* *$ \\
\hline $5-13 \mathrm{WK}$ & $65.68 \pm 0.95^{\mathrm{a}}$ & $64.74 \pm 0.92^{\mathrm{b}}$ & $57.93 \pm 0.75^{\mathrm{c}}$ & $* *$ \\
\hline \multicolumn{5}{|c|}{ Feed conversion ratio ( $\mathrm{g}$ feed / g gain) } \\
\hline $5-9 \mathrm{WK}$ & $3.35 \pm 0.18^{\mathrm{a}}$ & $3.02 \pm 0.16^{\mathrm{ab}}$ & $2.85 \pm 0.11^{b}$ & $*$ \\
\hline 9-13WK & $3.34 \pm 0.13^{\mathrm{a}}$ & $3.02 \pm 0.14^{\mathrm{ab}}$ & $2.76+0.12^{\mathrm{b}}$ & $*$ \\
\hline $5-13 \mathrm{WK}$ & $3.32+0.12^{\mathrm{a}}$ & $2.98+0.09^{\mathrm{b}}$ & $2.78+.06^{\mathrm{b}}$ & $* *$ \\
\hline Growth Performance index & $48.03 \pm 2.76^{b}$ & $57.02 \pm 3.31^{\mathrm{a}}$ & $59.27 \pm 2.90^{\mathrm{a}}$ & $* *$ \\
\hline Mortality rate $(\%)$ & 12.50 & $8 . \overline{33}$ & $8 . \overline{33}$ & NS \\
\hline Total feed cost (LE) & $11.44 \pm 0.16^{\mathrm{a}}$ & $11.11 \pm 0.16^{\mathrm{a}}$ & $9.63 \pm 0.13^{b}$ & $* *$ \\
\hline Price of total gain (LE) & $30.13 \pm 1.06$ & $32.91 \pm 1.29$ & $31.72^{\mathrm{a}} \pm 1.09$ & NS \\
\hline Net revenue & $19.01+1.03^{b}$ & $21.80 \pm 1.19^{\mathrm{a}}$ & $21.64 \pm 0.98^{\mathrm{a}}$ & $*$ \\
\hline Economic efficiency (\%) & $171.19^{c}+9.49^{b}$ & $197.65 \pm 9.4^{\mathrm{a}}$ & $214.24 \pm 7.62^{\mathrm{a}}$ & $* *$ \\
\hline
\end{tabular}

Note: $\mathrm{a}, \mathrm{b}, \mathrm{c}=$ Means in the same row with different superscript differ significantly $(P<0.05) . \mathrm{SE}=$ Standard Error of Means; NS = Not significantly different $(\mathrm{P}>0.05)$; $*=$ Significantly different $(P<0.05) ; * *=$ Significantly different $(P<0.01)$.

of several nutrients in moringa leaves that stimulate growth and increase the nutrients bioavailability and feed utilization such as high quality protein, vitamins, minerals, antioxidants and cytokinine-type hormones (Estrella et 
al., 2000, Fuglie, 2001, Siddhuraju and Becker, 2003, Fahey, 2005 and Yang et al., 2006).

The significant increase in economic efficiencyin rabbits fed MOLM diets is due to the improvement in feed conversion ratio and lower feed cost of MOLM diets.

The obtained results demonstrate that Moringa oleifera leaves meal (MOLM) possess good protein source and could be safely included in the diet of growing rabbits up to $19 \%$ as a substitution for about $75 \%$ of soya bean meal without negative effects on growth performance traits of rabbits.Inclusion of MOLM in the diet of rabbits in range of $12.5-19 \%$ decreases the cost of feeding and increases the economic efficiency (\%).

In this concern, most of the previous studies in the literature review indicated thatMOLM can be used safely in the diet of rabbits at level up to 10- $15 \%$ as a potential replacement for soybean meal (Odetola et al, 2012, Dougnon et al,2012, Yakubu et al ,2013 and Ghomsi et al,2017). However, In otherstudies, MOLM was included successfully at level of $20 \%$ (Nuhu, 2010 ) or $30 \%$ (Dahouda et al, 2013), and up to $40 \%$ of the diet (Safwat et $a l, 2014)$.The variation and the discrepancy in the results of these studies may be due to the variation in number of rabbits used and the differences in the chemical analysis of MOLMwhich lead toformulation of unbalanced experimentaldiets.

\section{Nutrients digestibility and feeding values:}

Table 4 shows the nutrients apparent digestion coefficients and feeding value of the experimental diets. Apparent digestion coefficients (\%) of DM, EE, CF and NFE were not significantly affected by the dietary treatments and were statistically similar among all the rabbit groups. Crude protein (CP) and $\mathrm{OM}$ digestibility coefficients were significantly improved $(\mathrm{P}<0.01$ and 0.05$)$ with rabbits fed MOLM diets than with those fed the control diet (without MOLM).

The nutritive values (\%) of MOLM diets expressed as DCP and TDN were significantly $(\mathrm{P}<0.01)$ higher in MOLM diets than the control diet. However, the nutritive value expressed as ME (Kcal / Kg diet DM) was statistically similar for the tested experimental diets.

The improvement in $\mathrm{CP}$ and $\mathrm{OM}$ digestibility and the nutritive value of MOLM diets could be attributed to that moringa leaves rich in vitamins and trace elements which introduce in composition or stimulate many of enzymes or co-enzymes responsible for the digestion and metabolism of nutrients inside the body of animal (Fahey, 2005). 


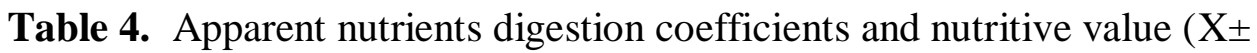
$\mathrm{SE})$ of the experimental diets fed to growing NZW rabbits.

\begin{tabular}{|l|c|c|c|c|}
\hline \multirow{2}{*}{ Parameters } & \multicolumn{4}{|c|}{ Experimental groups (\%) } \\
\cline { 2 - 5 } & $\begin{array}{c}\text { Control } \\
(\mathbf{0 . 0} \text { MOLM) }\end{array}$ & $\begin{array}{c}\text { 12.5 } \\
\text { MOLM }\end{array}$ & $\begin{array}{c}\text { 19.0 } \\
\text { MOLM }\end{array}$ & Sig. \\
\hline $\mathrm{DM}(\%)$ & $64.02 \pm 0.34$ & $65.38 \pm 0.78$ & $65.23 \pm 0.2$ & $\mathrm{NS}$ \\
\hline $\mathrm{OM}(\%)$ & $64.73 \pm 0.24^{\mathrm{b}}$ & $66.11 \pm 0.81^{\mathrm{a}}$ & $66.97 \pm 0.25^{\mathrm{a}}$ & $*$ \\
\hline $\mathrm{CP}(\%)$ & $68.89 \pm 0.37^{\mathrm{c}}$ & $74.43 \pm 0.62^{\mathrm{b}}$ & $76.13 \pm 0.18^{\mathrm{a}}$ & $* *$ \\
\hline $\mathrm{EE}(\%)$ & $67.12 \pm 0.69$ & $67.96 \pm 0.2$ & $68.51 \pm 0.31$ & $\mathrm{NS}$ \\
\hline $\mathrm{CF}(\%)$ & $46.21 \pm 0.22$ & $47.88 \pm 0.84$ & $48.3 \pm 0.48$ & $\mathrm{NS}$ \\
\hline $\mathrm{NFE}(\%)$ & $67.37 \pm 0.28$ & $67.1 \pm 1.04$ & $67.75 \pm 0.24$ & $\mathrm{NS}$ \\
\hline $\mathrm{DCP}(\%)$ & $11.59 \pm 0.06^{\mathrm{b}}$ & $12.35 \pm 0.10^{\mathrm{a}}$ & $12.49 \pm 0.03^{\mathrm{a}}$ & $* *$ \\
\hline $\mathrm{TDN}(\%)$ & $54.22 \pm 0.22^{\mathrm{b}}$ & $56.02 \pm 0.66^{\mathrm{a}}$ & $57.10 \pm 0.21^{\mathrm{a}}$ & $* *$ \\
\hline $\mathrm{ME}(\mathrm{Kcal} / \mathrm{Kg} \mathrm{DM})$ & $2649.72 \pm 13.26$ & $2703.13 \pm 30.58$ & $2697.28 \pm 7.99$ & $\mathrm{NS}$ \\
\hline $\mathrm{N}$
\end{tabular}

Note: $\mathrm{a}, \mathrm{b}, \mathrm{c}=$ Means in the same row with different superscript differ significantly $(P<0.05) . \mathrm{SE}=\mathrm{Standard}$ Error of Means; NS $=$ Not significantly different $(P>0.05) ; *=$ significantly different $(P<0.05)$; $* *=$ significantly different $(P<0.01)$.

The obtained results were in agreement with those reported by Olatunji et al (2015) and Nuhu (2010) who reported that feeding growing rabbits graded levels of MOLM up to $20 \%$ of the diet in replacement of soya bean meal showed significant $(\mathrm{P}<0.05)$ improvement in $\mathrm{DM}$ and $\mathrm{CP}$ digestibility of MOLM diets. Digestibility coefficients of CF and EE were not significantly affected by the dietary treatment and were statistically similar in all rabbit groups.

\section{Haematological and biochemical parameters of blood of rabbits:}

Data in Table 5 show the haematological parameters of blood of growing rabbitsfed for 8 weeks different levels of MOLM in the diet as replacement for soya bean meal. As shown in Table 5, all the haematological blood parameters were not significantly affected by the dietary treatments, with exception of $\mathrm{RBCs}$ which were significantly $(\mathrm{P}<$ $0.05)$ higher, whereas $\mathrm{MCH}$ was significantly $(\mathrm{P}<0.05)$ lower with rabbits fed MOLM diets compared to those fed the control. However, all the haematological parameters values were within the normal physiological range for healthy rabbits according to Hewittet al (1989), Archetti et al (2008) Isaac et al (2013) and Etim et al (2014).

The present findings of the study agree with Nuhu (2010) and Olatunji et al (2015) who reported that feeding growing rabbits for 8 weeks on diets containing graded levels of MOLM up to $20 \%$ had no significant effects on the haematological parameters of rabbits, including, RBC, WBC, Hb, PCV, $\mathrm{MCV}, \mathrm{MCH}, \mathrm{MCHC}$, lymphocytes, monocytes and neutrophils. 
Table 5. Haematological parameters of blood $(\mathrm{X} \pm \mathrm{SE}) *$ of growing NZW rabbits fed the experimental diets.

\begin{tabular}{|c|c|c|c|c|}
\hline \multirow[t]{2}{*}{ Parameters } & \multicolumn{4}{|c|}{ Experimental groups (\%) } \\
\hline & $\begin{array}{c}\text { Control } \\
(0.0 \text { MOLM) }\end{array}$ & $\begin{array}{c}12.5 \\
\text { MOLM }\end{array}$ & $\begin{array}{c}19.0 \\
\text { MOLM }\end{array}$ & Sig. \\
\hline $\mathrm{RBCs}\left(\times 10^{6} / \mathrm{ml}\right)$ & $5.41+0.14^{\mathrm{b}}$ & $5.92+0.17^{\mathrm{a}}$ & $6.20+0.12^{\mathrm{a}}$ & * \\
\hline WBCs $\left(\times 10^{3} / \mathrm{ml}\right)$ & $8.22+0.82$ & $9.28 \pm 1.26$ & $7.5 \pm 0.4$ & NS \\
\hline Neutrophil (\%) & $29.80 \pm 6.76$ & $21.40 \pm 8.66$ & $23.80+4.46$ & NS \\
\hline Lymphocyte (\%) & $55.60 \pm 7.50$ & $57.20 \pm 6.68$ & $60.00 \pm 3.17$ & NS \\
\hline Haemoglobin $(\mathrm{g} / \mathrm{dl})$ & $11.34+0.31$ & $12.04+0.36$ & $11.86+0.12$ & NS \\
\hline Platelets $\left(\times 10^{3} / \mathrm{ml}\right)$ & $286.2+27.21$ & $321.2+54.71$ & $271.2+40.99$ & NS \\
\hline $\mathrm{HCT}(\%)$ & $36.76 \pm 0.58$ & $39.04 \pm 1.1$ & $39.0 \pm 0.53$ & NS \\
\hline $\operatorname{MCV}(\mathrm{f} / \mathrm{l})$ & $68.26 \pm 1.95$ & $66.02 \pm 1.35$ & $63.02 \pm 1.38$ & NS \\
\hline $\mathrm{MCH}(\mathrm{pg})$ & $20.88 \pm 0.48^{\mathrm{a}}$ & $20.36 \pm 0.45^{\mathrm{ab}}$ & $19.180 .36^{\mathrm{b}}$ & $*$ \\
\hline $\mathrm{MCHC}(\mathrm{g} / \mathrm{dl})$ & $30.6+0.29$ & $30.84+0.22$ & $29+1.53$ & NS \\
\hline
\end{tabular}

*Mean of 5values for each parameter. Note: RBCs = Red blood cells, WBCs $=$ White blood cells, $\mathrm{HCT}=$ Haematocrit, $\mathrm{MCV}=$ Mean corpuscular volume, $\mathrm{MCH}=$ Mean corpuscular haemoglobin, $\mathrm{MCHC}=$ Meancorpuscular haemoglobin concentration .

Note: $\mathrm{a}, \mathrm{b}, \mathrm{c}=$ Means in the same row with different superscript differ significantly $(P<0.05) . \mathrm{SE}=$ Standard Error of Means; NS = Not significantly different $(P>0.05) ; *=$ significantly different $(P<0.05)$.

Data in Table 6 show blood biochemical parameters of growing rabbitsfed the experimental diets. The results of serum biochemical parameters presented in Table 6 show no significant dietary influence on albumin, globulin ,urea- $\mathrm{N}$, creatinine andtotal bilirubin, however total protein level and globulin were higher $(\mathrm{P}<0.01)$ and cholesterol level was lower $(\mathrm{P}<$ $0.05)$ with rabbits fed19 \% MOLM diet compared with those fed the control or12.5\% MOLM diet.

The reduction in cholesterol level with increase in MOLM in the diet suggests that MOLM has a cholesterol lowering effect.

The results of serum total protein levels of rabbit groups support the results obtained of daily body gain and feed conversion ratio which showed the best values with rabbits fed $19 \%$ MOLM diet in replacement of $75 \%$ of soya bean.

The present findings agree with those reported by Olatunji et al (2015) who reported that Albumin, globulin, total protein, SGPT, SGOT and ALP were not significantly affected $(\mathrm{P}>0.05)$ in blood serum of rabbits fed diets containing graded levels of MOLM up to $20(\%)$.

It is apparent that MOLM did not negatively affect the haematological and biochemical indices of the experimental rabbits and the obtained results 
Table 6. Blood biochemical parameters $(X \pm S E) *$ of growing NZW rabbits fed for 8 weeks diets containing different levels of MOLM as a substitution for soya bean meal.

\begin{tabular}{|l|c|c|c|c|}
\hline \multirow{2}{*}{ Parameters } & \multicolumn{3}{|c|}{ Experimental groups (\%) } \\
\cline { 2 - 5 } & $\begin{array}{c}\text { Control } \\
(\mathbf{0 . 0} \text { MOLM) }\end{array}$ & $\begin{array}{c}\mathbf{1 2 . 5} \\
\text { MOLM } \\
\text { MOLM }\end{array}$ & Sig. \\
\hline ALT (U/L) & $48.08 \pm 8.21$ & $48.54 \pm 5.23$ & $54.8 \pm 9.05$ & NS \\
\hline AST (U/L) & $37.0 \pm 4.92$ & $40.0 \pm 1.95$ & $37.0 \pm 3.78$ & NS \\
\hline Total protein (g/dl) & $6.09 \pm 0.17^{\mathrm{b}}$ & $6.29 \pm 0.21^{\mathrm{b}}$ & $7.24+0.20^{\mathrm{a}}$ & $* *$ \\
\hline Albumin (g/dl) & $4.09 \pm 0.22$ & $4.25 \pm 0.15$ & $4.02 \pm 0.18$ & NS \\
\hline Globulin ( g/dl) & $1.99 \pm 0.13^{\mathrm{b}}$ & $2.03 \pm 0.19^{\mathrm{b}}$ & $3.22 \pm 0.31^{\mathrm{a}}$ & $* *$ \\
\hline A/G ratio & $2.06 \pm 0.24^{\mathrm{a}}$ & $2.09 \pm 0.24^{\mathrm{a}}$ & $1.25 \pm 0.17^{\mathrm{b}}$ & $*$ \\
\hline Total bilirubin (mg/dl) & $0.43 \pm 0.04$ & $0.46 \pm 0.05$ & $0.48 \pm 0.07$ & NS \\
\hline Urea-N (mg/dl) & $18.2 \pm 1.69$ & $18.2 \pm 0.86$ & $16.0 \pm 0.71$ & NS \\
\hline Creatinine (mg/dl) & $0.86 \pm 0.03$ & $1.1 \pm 0.07$ & $1.02 \pm 0.09$ & NS \\
\hline Cholesterol (mg/dl) & $92.4 \pm 1.12^{\mathrm{a}}$ & $91.6 \pm 1.69^{\mathrm{a}}$ & $85.6 \pm 1.54^{\mathrm{b}}$ & $*$ \\
\hline
\end{tabular}

*Mean of 5 values for each parameter. ALT = Alanine transaminase, AST = Aspartate transaminase, Urea-N = Ureanitrogen.

Note: $\mathrm{a}, \mathrm{b}, \mathrm{c}=$ Means in the same row with different superscript differ significantly $(P<0.05)$.

$\mathrm{SE}=$ Standard Error of Means; NS = Not significantly different $(P>0.05) ; *=$ significantly different $(P<0.05) ; * *=$ significantly different $(P<0.01)$.

were within the normalphysiological range for healthy rabbits as reported by Hewittet al (1989), Archetti et al (2008) and Etim et al (2014).

\section{Carcass traits:}

Data presented in Table (7) show carcass traits of rabbits fed the experimental diets.

Carcass traits were not significantly influenced by the dietary treatments and all traits were statistically similar between rabbit groups. The carcass percentages recorded 46.51, 48.0 and $47.22 \%$, while dressing percentages were 52.34, 54.04 and $53.42 \%$ for rabbit groups fed zero 
Table 7.Carcass traits $(\mathrm{X} \pm \mathrm{SE})^{*}$ of growing NZW rabbits fed the experimental diets.

\begin{tabular}{|c|c|c|c|c|}
\hline \multirow[t]{2}{*}{ Parameters } & \multicolumn{4}{|c|}{ Experimental groups (\%) } \\
\hline & $\begin{array}{c}\text { Control } \\
(0.0 \text { MOLM })\end{array}$ & $\begin{array}{c}12.5 \\
\text { MOLM }\end{array}$ & $\begin{array}{c}19.0 \\
\text { MOLM }\end{array}$ & Sig. \\
\hline Pre slaughter weight (g) & $1878 \pm 61.96$ & $2045.6 \pm 94.65$ & $2033.4+49.48$ & NS \\
\hline After slaughter Weight (g) & $1832+58.56$ & $1981.8+91.63$ & $1974.2 \pm 48.56$ & $\mathrm{NS}$ \\
\hline $\begin{array}{ll}\text { Carcass weight } & (\mathrm{g}) \\
& (\%)\end{array}$ & $\begin{array}{c}874.6+39.47 \\
46.51+0.85\end{array}$ & $\begin{array}{c}981.4 \pm 45.55 \\
48.00 \pm 0.65\end{array}$ & $\begin{array}{c}959.8+21.19 \\
47.22+0.32\end{array}$ & $\begin{array}{l}\text { NS } \\
\text { NS }\end{array}$ \\
\hline $\begin{array}{ll}\text { Liver weight } & (\mathrm{g}) \\
& (\%) \\
\end{array}$ & $\begin{array}{l}75.2 \pm 7.00 \\
4.00 \pm 0.31 \\
\end{array}$ & $\begin{array}{l}92.0 \pm 9.34 \\
4.55 \pm 0.52\end{array}$ & $\begin{array}{c}94.2 \pm 14.67 \\
4.62 \pm 0.70\end{array}$ & $\begin{array}{l}\text { NS } \\
\text { NS }\end{array}$ \\
\hline $\begin{array}{ll}\text { Heart weight } & (\mathrm{g}) \\
& (\%)\end{array}$ & $\begin{array}{l}9.00 \pm 0.84 \\
0.48 \pm 0.04\end{array}$ & $\begin{array}{l}7.80 \pm 0.97 \\
0.38 \pm 0.03\end{array}$ & $\begin{array}{l}8.80 \pm 0.66 \\
0.43 \pm 0.03\end{array}$ & $\begin{array}{l}\text { NS } \\
\text { NS }\end{array}$ \\
\hline $\begin{array}{ll}\text { Kidney weight } & (\mathrm{g}) \\
& (\%)\end{array}$ & $\begin{array}{l}24.4 \pm 1.69 \\
1.30 \pm 0.07\end{array}$ & $\begin{array}{l}24.2 \pm 1.02 \\
1.18+0.05\end{array}$ & $\begin{array}{l}23.6+1.63 \\
1.16+0.09\end{array}$ & $\begin{array}{l}\text { NS } \\
\text { NS }\end{array}$ \\
\hline $\begin{array}{ll}\text { Giblets weight } & (\mathrm{g}) \\
& (\%)\end{array}$ & $\begin{array}{c}108.6 \pm 7.76 \\
5.77 \pm 0.29\end{array}$ & $\begin{array}{c}124.0 \pm 9.19 \\
6.11 \pm 0.51\end{array}$ & $\begin{array}{c}126.6 \pm 13.53 \\
6.21 \pm 0.63\end{array}$ & $\begin{array}{l}\text { NS } \\
\text { NS }\end{array}$ \\
\hline Lung weight & $\begin{array}{l}10.2 \pm 0.58 \\
0.54 \pm 0.03\end{array}$ & $\begin{array}{c}9.6 \pm 1.29 \\
0.46 \pm 0.04\end{array}$ & $\begin{array}{l}10.8 \pm 0.97 \\
0.53 \pm 0.04\end{array}$ & $\begin{array}{l}\text { NS } \\
\text { NS }\end{array}$ \\
\hline $\begin{array}{ll}\text { Spleen weight } & (\mathrm{g}) \\
& (\%)\end{array}$ & $\begin{array}{c}1.00 \pm 0.0 \\
0.05 \pm 0.002\end{array}$ & $\begin{array}{c}1.20 \pm 0.2 \\
0.06 \pm 0.01\end{array}$ & $\begin{array}{l}1.20 \pm 0.2 \\
0.06 \pm 0.01\end{array}$ & $\begin{array}{l}\mathrm{NS} \\
\mathrm{NS}\end{array}$ \\
\hline $\begin{array}{r}\text { Dressing weight }(\mathrm{g}) \\
(\%)\end{array}$ & $\begin{array}{c}983.2 \pm 45.39 \\
52.34 \pm 1.01\end{array}$ & $\begin{array}{c}1105.4 \pm 45.26 \\
54.04 \pm 0.62\end{array}$ & $\begin{array}{c}1086.4 \pm 29.63 \\
53.43 \pm 0.74\end{array}$ & $\begin{array}{l}\text { NS } \\
\text { NS }\end{array}$ \\
\hline
\end{tabular}

*Mean of 5 values for each trait, where 5 rabbits were slaughtered in each group.

Note: $\mathrm{a}, \mathrm{b}, \mathrm{c}=$ Means in the same row with different superscript differ significantly $(P<0.05)$.

$\mathrm{SE}=$ Standard Error of Means; NS $=$ Not significantly different $(P>0.05)$.

(control), $12.5 \%$ and $19 \%$ MOLM diets, respectively.Internal organs, including liver, kidney, heart, lungs and spleen appeared normal in size and did not show any signs of toxicity.

The present findings agree with those recorded by Abubakaret al (2015) who reported that dressing and internal organs percentages were not significantly affected in rabbit groups fed for 8 weeks diets containing 0,15 , 30 and $45 \%$ MOLM.The same results were obtained by Nuhu (2010) when rabbits were fed diets containing 0, 5, 10, 15 and $20 \%$ MOLM. However, Ghomsi et al (2017) observedthat carcass and dressed weights of growing rabbits were significantly $(\mathrm{P}<0.05)$ decreased by feeding basal diet contained 20\% MOLM compared with those fed the control or 10\% MOLM diets. The discrepancy in the indicated results may be due to the variation in the composition of the experimental diets, number of rabbits used in each group and using unbalanced diets. 
Conclusively, based on the results of the present study, it was concluded that growing rabbits can utilize varying levels of Moringaoleifera leaves meal up to $19 \%$ to substitute up to $75 \%$ of soya bean meal of the formulated diets without any adverse effects on growth performance, nutrients utilization, blood constituents, carcass traits and elevated the economic efficiency.

\section{REFERENCES}

Abubakar, M. ; Ibrahim, U. ; Yusuf, A. U. ; Muhammad, A. S. and Adamu, N (2015). Growth performance, carcass and organ characteristics of growing rabbits fed graded levels of moringa oleifera leaf meal in diets. Bayero Journal of Pure and Applied Sciences, 8(2): $7-9$.

Archetti I. ; Tittarelli C. ; Cerioli M. ; Brivio R. ; Grilli G. and Lavazza A (2008). Serum Chemistry and Hematology values in commercial rabbits: Preliminary data from industrial farms in Northern Italy. 9th World Rabbit Congress - June 10-13, Verona - Italy, pp:1147- 1151

Asaolu, V.O; Odeyinko, S. M; Akinbamjo, O. O and Sodeinde, F. G (2009). Feed intake, nutrient digestibility and nitrogen balance of graded levels of moringa and bamboo leaves by West African dwarf goats. Bull. Anim. Health Prod. Afr, 4: 361-368.

Bennett, R.N. ; Mellon, F.A. ; Foidl, N. ; Pratt, J.H. ; DuPont, M.S. ; Perkins, L. and Kroon, P.A (2003).Profiling glucosinolates and phenolic in vegetative and reproductive tissues of the multi-purpose trees Moringa oleifera L. (Horse radish tree) and Moringa Stenopetala L. Journal of Agriculture and Food Chemistry, 51: 3546-3553.

Broody, S (1945).Bioenergetics and growth. Reinhold Publishing Company, N.Y.

Cheeke, P.R. ; Patton, N. M. and Templeton, G. S (1982).Rabbits Production. $5^{\text {th }}$ Ed., Interstate Printers and Publishers Inc. Danville, IL, USA.

Dahouda, M. ; Adjolohoun, S. ; Senou, M. ; Toleba, S. S. ; Abou, M. ; Vidjannagni, D. S. ; Kpodékon, M. and Youssao, A. K. I ( 2013). Effects of diets containing Moringa oleifera Lam leaves and commericial feed on rabbit (Oryctolagus cuniculus) growth performance and meat quality. Int. J. Biol. Chem. Sci., 7 (5): 18381852. 
De Blas, $\mathbf{C}$ and Wiseman, $\mathbf{J}$ (2010).Nutrition of the rabbit.The $2{ }^{\text {nd }}$ edition, CABI Publishing, Wallingford, UK.344 pp.

Dougnon T J; Aboh B A; Kpodékon T M; Honvou, $\mathrm{S}$ and Youssao. (2012).Effects of substitution of pellet of Moringa oleifera to commercial feedon rabbit's digestion, growth performance and carcass trait.J. Appl. Pharm. Sci.; 2 (9): 015-019.

Duncan, D. B. (1955). Multiple Range Tests and Multiple F. Tests. Biometrics. 11:1-42.

El Tazi, S M (2014).Effect of feeding different levels of Moringa Oleifera leaf meal on the performance and carcass quality of broiler chicks.International Journal of Science and Research (IJSR), Volume 3 Issue 5, May 2014 , ISSN (Online): www.ijsr.net,pp: 147- 151.

Estrella, M.C.P. ; Mantaring, J.B.V. and David, G.Z (2000). A double blind, randomized controlled trial on the use of malunggay (Moringa oleifera) for augmentation of the volume of breast milk among nonnursing mothers of preterm infant. The Philippine Journal of Pediatric, 49: 3-6.

Etim,N.N, Enyenihi,G.E, Akpabio,U and Offiong, E. A (2014). Effects of nutrition on haematology of rabbits: A review. European Scientific Journal January, Vol.10, No.3, 413- 424.

Fadiyimu, A.A,Alokan, J. A. and Fajemisin, A.N (2010). Digestibility, nitrogen balance and hematological profile of West African dwarf sheep fed alternative levels of moringa oleifera as supplement to panicum maximum. J. Animal Science., 6:634-643.

FAO (2014).Statistical Yearbook, Africa Food and Agriculture .Food and Agriculture Organization, Rome. www.fao.org

Fahey, J. W (2005).Moringa oleifera: A Review of the medical evidence for its nutritional, therapeutic, and prophylactic properties. Part 1.Trees for Life Journal (on line):1-5,http://www.trees for life journal.org/article.php/2005.

Ferreira, P.P, Farias, D.F, Oliveira, J.T. and Carvalho, A.U (2008). Moringa oleifera: bioactive compounds and nutritional potential. Nutrition Review, Campinas, 21(4):431-437.

Foidl, N., Makkar, H.P.S. and Becker, K (2001). The potential of Moringa oleifera for agricultural and industrial uses.In: The Miracle Tree, pp. 45-76, The Multiple Attributes of Moringa (Ed) Lowell J. Fuglie, CTA, Wageningen, The Netherlands. http://www.moringanews.org/actes/foidl en.doc. 
Fuglie, L.J (2001).Natural Nutrition for the Tropics. In: Fubalie, L.J. (ed). The Miracle Tree: The Multiple Attributes of Moringa. CTA Publication, Wageningen, The Netherlands, pp. 103-115.

Ghomsi, MO, Enow, JT, Etchu, KA, Tientcheu, BL, Enamou, G, Chouengouong, TM, Mongo, B.G, and Bayemi P.H (2017).Effect of Moringa Oleifera leaf meal (Molm) on the growth, carcass, hematology and biochemical parameters of rabbits.www.symbiosis on line publishing.com

Hewitt, C.D, Innes, D.J, and Wills, M.R (1989).Normal biochemical and hematological values of blood in New Zealand White rabbits.Clinical Chemistry, 35 (8), 1777- 1779.

Isaac, L. J., Abah, G., Akpan, B. and Ekaette, I. U (2013).Haematological properties of different breeds and sexes of rabbits.Proc. of the 18th Annual Conf. of Anim. Sci. Assoc. of Nigeria, 24-27.

Jain, N.C (1986). Scanning electron micrograph of blood cells. In: Schalms Veterinary Haematology. $4^{\text {th }}$ edition, Philadelphia: Lea and Fibiger., USA, 4: 63- 70.

Kalogen, U.A (1985).Rabbits Nutrition (In Russian).Agropromozdat Publishing, Moscow, Russia.

Makker, H.S. and Becker.(1997).Nutrients and anti- quality factors in different morphological parts of the moringa olifera tree.Journal of Agricultural Science. (Cambridge), 128(3): 311-322.

Makkar, H. P; Francis, G. and Becker, K (2007).Bioactivity of phytochemicals in some lesser-known plants and their effects and potential applications in livestock and aquaculture production systems.J. Animal Research, 1 (9): 1371-1391

Melesse, A.; Tiruneh, W andNegesse, T (2011). Effects of feeding Moringa stenopetala leaf meal on nutrient intake and growth performance of Rhode Island Red chicks under tropical climate. Trop. Subtrop. Agroecosyst., 14 (2): 485-492.

Mendieta-Araica, M. B.; Spörndly, E. ; Sánchez, N. R and Spörndly, R. ( 2011). Feeding moringa oleifera fresh or ensiled to dairy cowsEffects on milk yield and milk flavor. Trop Anim. Health Prod, DOI 10.1007/s11250-011-9803-7.Published online.

Moyo, B., Masika, P.J., Hugo, A. and Muchenje, V (2011). Nutritional characterization of Moringa (Moringa oleifera Lam.) leaves. African Journal of Biotechnology, 10 (60): 12925 - 12933. 
NRC (1977). Nutrient Requirement of Domestic Animal, Nutrient Requirement of Rabbits. Second Edition National Academy of Science Washington D.C.,USA.

North, M.O (1981).Commercial chicken production.Annual, 2 nd Edition.ABVPublishing Company, Inc., West Post Connicticut, USA.

Nuhu,F (2010).Effect of moringa leaf meal on nutrient digestibility, growth, carcass and blood indices of weaned rabbits.Master of Science Thesis, Faculty of Agriculture and Natural Resources , Kwame Nkrumah University of Science and Technology, Kumasi (Ghana),122 p.

Odetola, O.M; Adetola, O.O; Ijadunola, T.I; Unknown, O.y and Adu, OA (2012). Utilization of Moringa ( Moringa oleifera) leaves meal as a replacement for soya bean meal in rabbit's diets. Schol.J. buyers. Sci., 2 (12): 309-313.

Olatunji A. K; Alagbe, O. J and Hammed, M.A (2015). Effect of Varying Levels of Moringa Olifera Leaf Meal on Performance and Blood Profile of Weaner Rabbits. International Journal of Science and Research (IJSR). ISSN (Online): 2319-7064

Olaofe, O.; Adeyeye, E. I. and Ojugba, S (2013). Comparative study of proximate amino acids and fatty acids of Moringa oleifera tree.Elixir Appl. Chem. 54: 12543-12554.

Perez, J. M.; Lebas, F. ;Gidenne, T. ; Maertens, L. ; Xiccato, G. ; Parigi-Bini, R. A. ; Dalle Zotte, R. M. ; Cossu, R. ; Carazzolo A. ; Villamide M. J. ; Carabaño R. ; Fraga M. J. ; Ramos M. ; A. Cervera; C. Blas; E. Fernández;J. ; Cunha, L. F. and Freire J. B. (1995).European reference method for in vivo determination of diet digestibility in rabbits. World Rabbit Sci. 3:41-43.

Price, M. L (2007).The MoringaTree. Nota Tecnica, ECHO, 17391.Durrance Road North Fort Myers, FL 33917, USA

Sanchez,N.R, Ledin,S and Ledin,I (2006).Biomass production and chemical composition of Moringa oleifera under different management regimes in Nicaragua.Agroforestry Systems. 66:231242. DOI 10.1007/s10457-005-8847-y, Springer 2006.

Safwat A. M., Sarmiento-Franco, L., Santos-Ricalde, R. H., Nieves D., and Sandova-Castro,C.A (2015).Estimating apparent nutrient digestibility of diets containing Leucaena leucocephala or Moringa oleifera Leaf Meals for Growing Rabbits by Two Methods.Asian Australas. J. Anim. Sci. Vol. 28, No. 8 : 1155-1162. http://dx.doi.org/10.5713/ajas.14.0429 
Safwat, A. M. ; Sarmiento-Franco, L. ; Santos-Ricalde, R. and Nieves, D (2014).Effect of dietary inclusion of Leucaena leucocephala or Moringa oleifera leaf meal on performance of growing rabbits.Trop. Anim. Health Prod., 46 (7): 1193-1198.

Sarwatt, S.V.; Milang'ha, M.S.; Lekule, F.P. and Madalla, N (2004).Moringa oleifera and cotton seed cake as supplements for smallholder dairy cows fed Napier grass. Livestock Research for Rural Development, 16 Art.\# 38.http //www.cipac.org.co //Irrd16 /6/sarw16038.

Sarwatt, S. V. ;Kapange, S. S. andKakengi, A. M. V (2002). Substituting sunflower seed-cake with Moringa oleifera leaves as a supplemental goat feed in Tanzania. Agroforestry Systems, 56 (3): 241-247.

Siddhuraju, $P$ and Becker $K$ (2003). Antioxidant properties of various solvent extracts of total phenolic constituents from three different agroclimatic origins of drumstick tree (Moringa oleifera Lam.) Leaves.Journal of Agricultural and Food Chemistry 51, 2144-2155.

Snedeccor,G.W and Cochran,W.G (1982).Statistical Methods. The $6^{\text {th }}$ edition, Towa State University Press, Ames, Iowa, USA.

SPSS (2004). Statistical Package for Social Science, Chicago, USA.

Ufele, A.N, Ebenebe, C.I, Igwe, I.I, Mogbo, T.C, Akunne, E.C andAziagba, B.O (2013). The Effects of Drumstick Tree (Moringa oleifera) Leaf Meal on the Average Weight Gain of Domestic Rabbits (Oryctolaguscuniculus). The Bioscientist.;1(1):106-108.

Walker, H.K, Hall, W.Dand Hurst, J.W (1990). Clinical Methods: The History, Physical, and Laboratory Examinations.The 3rd edition.Boston: Butterworths, USA.

Yakubu, B. ; Nathan, J. M. and Yahya, M. S (2013). Effects of substituting groundnut cake with moringa (Moringa Oleifera) leaf meal on growth performance, carcass yield and haematological profile of weaner rabbits. Journal of Science, Technology \& Education, Vol. 2, No. 1, 77- 84 .

Yang, R.Y.; Tsou, S.C.S.; Lee, T.C.; Chang, L.C.; Kuo, G. and Lai, P.Y. (2006). Moringa a novel plant rich in antioxidants, bio-available iron and nutrients. American Chemical Society Symposium, Series, 925: 224-239. 


\section{تأثير استبدال كسب فول الصويا بمسحوق أوراق المورينجا (Moringa oleifera) الغذائية_ مكونات الام ـ صفات الألبيحة في الأرانب.}

رمضان محمد أبو الحديد ـ مصطفي ابراهيم عبد الرحيم ـ دولت عبد العزيز الكرداوي

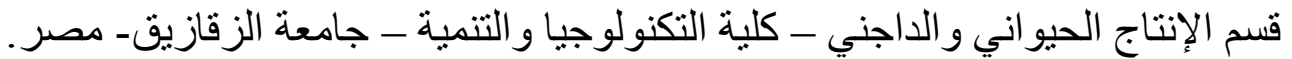

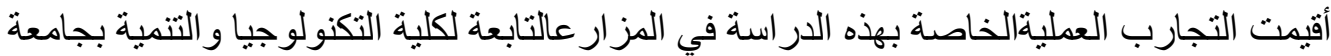

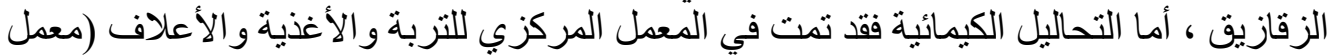

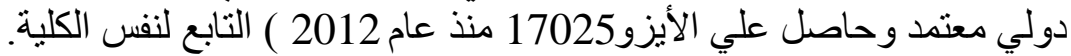

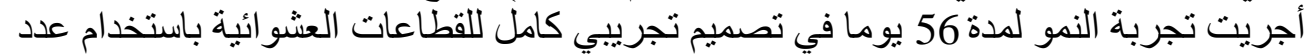

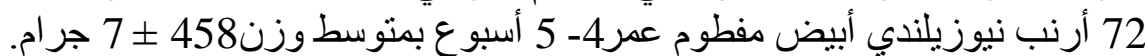

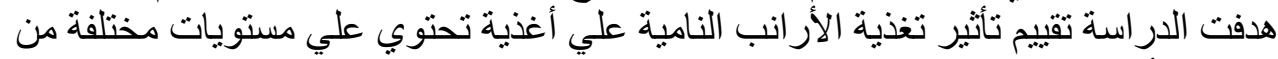

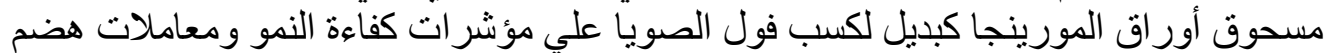

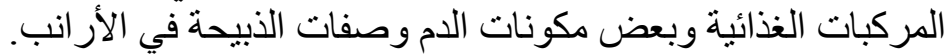

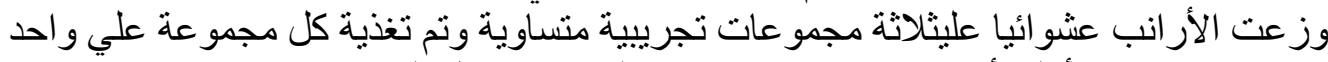

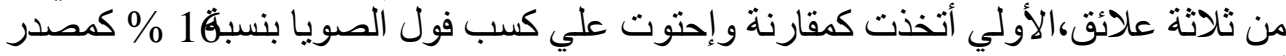

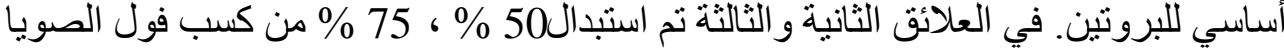

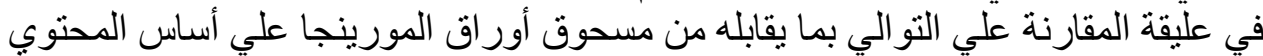

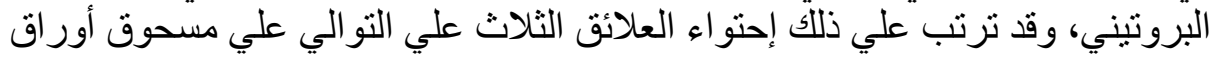

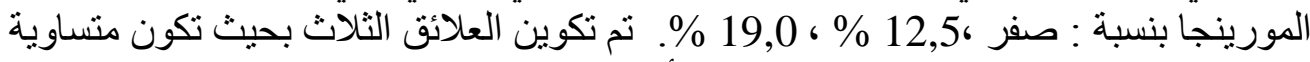
في محتو اها من البروتين و العناصر الغذائية الأخري وتلبي الإحتياجات الغذائية اللازمة لنمات النمو

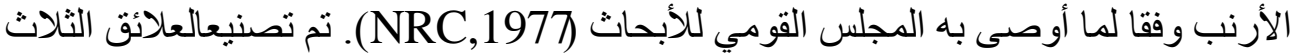

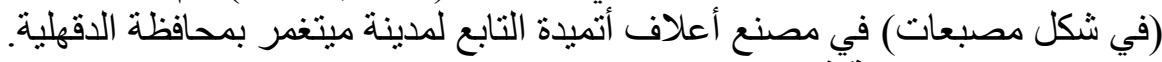

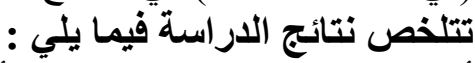

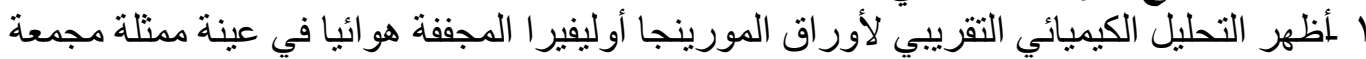
مأخوزة من 6 حشات متتالية من نبات المورينجا التركيب الغذائي الآني :

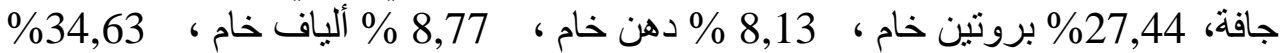

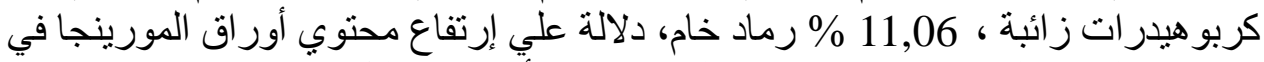

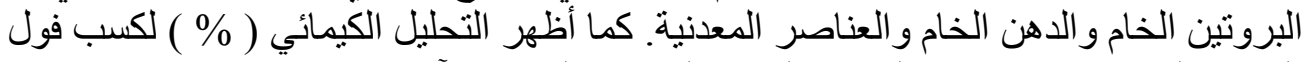

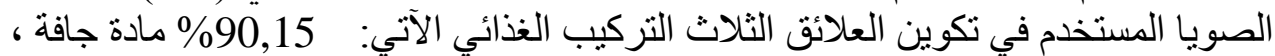

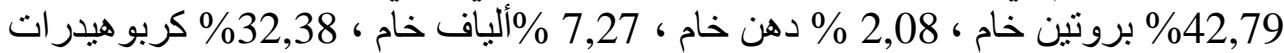

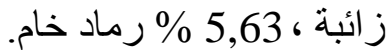


r ـتحسن بصورة غير معنوية كل من وزن الجسم النهائي و عائد الوزن اليومي وسر عة النمو ، بينما

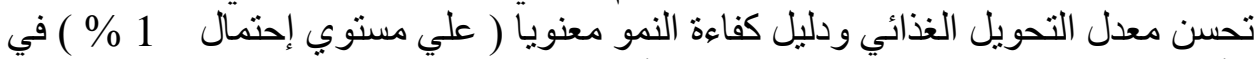

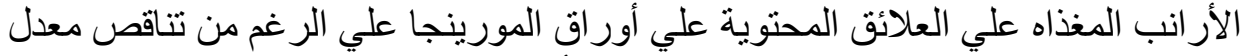

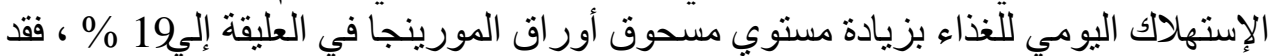

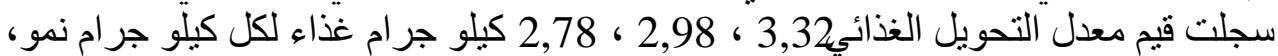

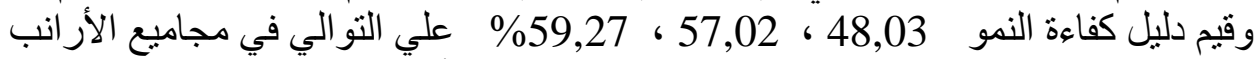

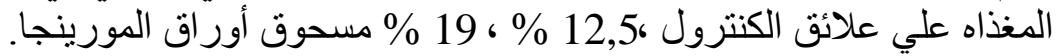

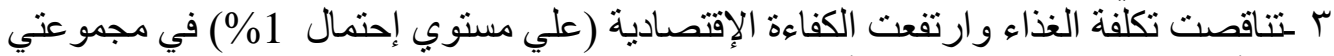

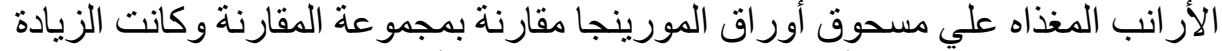

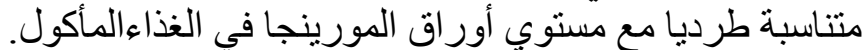

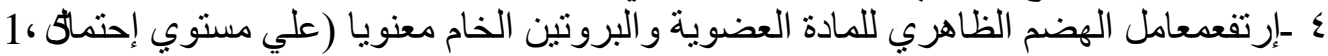

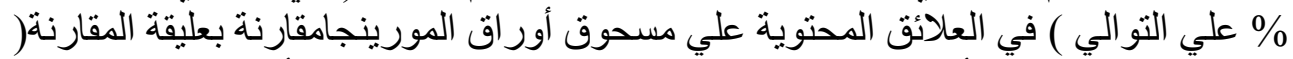

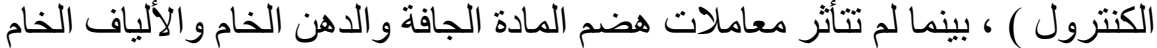
و الكربو هيدر ات الذائبة بالمعاملات الغئرة الغذائية.

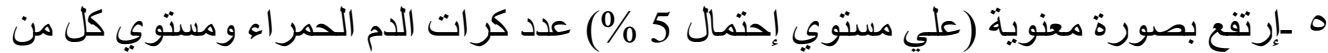

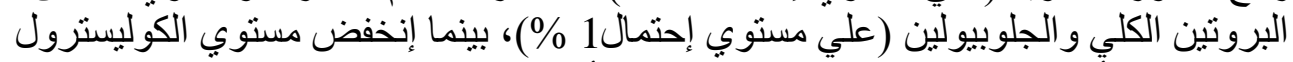

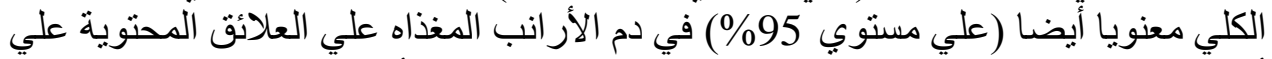

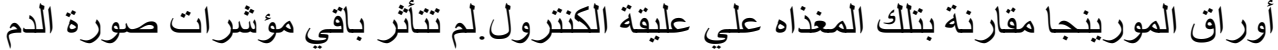

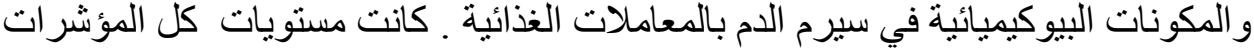

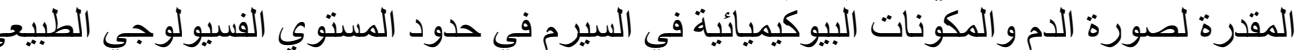

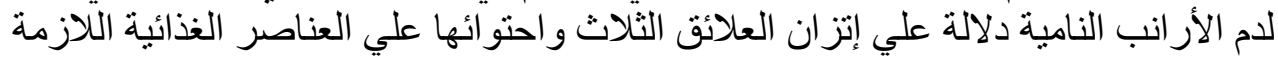
للنمو وخلو ها من المو اد السامة النة.

7 ـلم تتاثر معنويا صفات الذبيحة بالمعاملات الغذائية , فقد سجلت نسب الذبيحة و Carcass )

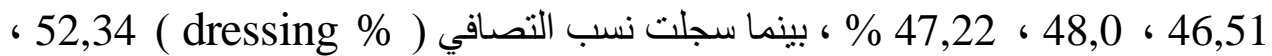

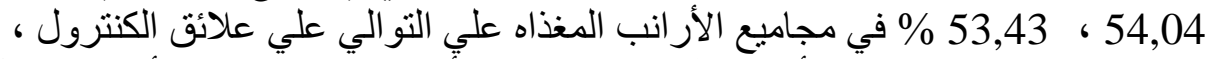

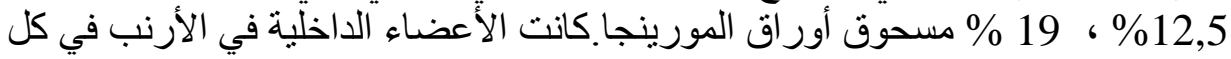

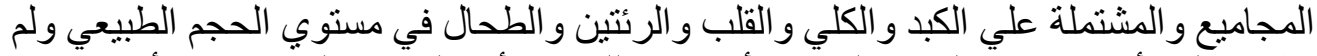

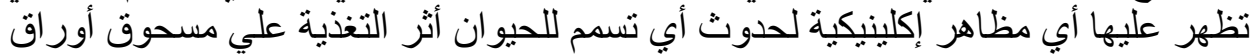

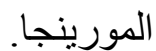

التوصية:تشير نتائج الدراسة الحالية علي أن أوراق المورينجا الجافة مصدر غني للبروتين

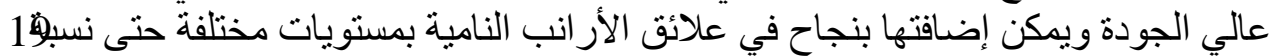
\% لكي تستبدل حتي 75 \% من كمية كسب فول الصنا الصويا في العليقة بدون أي تأثير ات ضات ضارة علي كفاءة النمو وهضم المركبات الغذائية ومكونات الدم وصفات الذبات فيحة. 
